A C G

publications

Org. Commun. 14:4 (2021) 365-376

organic

communications

\title{
Design, synthesis and antimicrobial screening of some new thienopyrimidines
}

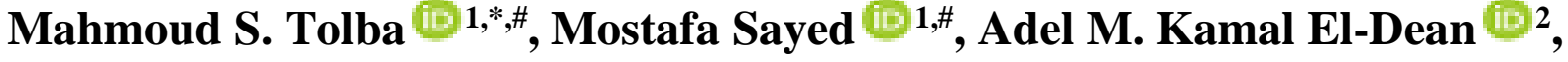 \\ Reda Hassanien ${ }^{1}$, , Shaban A. A. Abdel-Raheem ${ }^{3}{ }^{3}$ \\ and Mostafa Ahmed ${ }^{\odot} 1$
}

\author{
${ }^{1}$ Chemistry Department, Faculty of Science, New Valley University, El-Kharja 72511, Egypt \\ ${ }^{2}$ Chemistry Department, Faculty of Science, Assiut University, Assiut 71516, Egypt \\ ${ }^{3}$ Soils, Water, and Environment Research Institute, Agricultural Research Center, Giza, Egypt
}

(Received September 20, 2021; Revised November 14, 2021; Accepted, November 16, 2021)

\begin{abstract}
Heterocyclic compounds play an important role in our life due to their biological importance in the struggle of microorganisms. Herein, a series of novel hybrid compounds of thienopyrimidine with triazine and pyrimidine scaffolds were synthesized starting from difunctionalized compound 5-amino-4-phenyl-2-(p-tolylamino)thieno[2,3d]pyrimidine-6-carbonitrile (1). Moreover, the diazotization of compound 1 with sodium nitrite in an acidic medium gave the chloro-triazine compound 2 which was subjected to the nucleophilic substitution of chlorine atom with different nucleophiles delivered compounds $3 \mathrm{a}-5 \mathrm{c}$. Furthermore, the reaction of compound 1 with carbon disulfide led to the formation of dithione derivative 6 which was alkylated with ethyl chloroacetate to give compound 7 , on the other hand, the reaction of compound 1 with phenyl isothiocyanate produced 4-imino-3,9-diphenyl-7-(p-tolylamino)-3,4dihydropyrimido[ $\left[4^{\prime}, 5^{\prime}: 4,5\right]$ thieno $[2,3-d]$ pyrimidine-2(1H)-thione (8), while acylation of the amino group in compound 1 with acetic anhydride gave compound 9. All synthesized compounds were characterized by elemental and spectral analysis techniques (IR, ${ }^{1} \mathrm{H}$ NMR, ${ }^{13} \mathrm{C}$ NMR, Mass spectroscopy). Furthermore, the synthesized compounds were tested for their antimicrobial activity against different strains of bacteria and fungi, and the results obtained showed good to moderate activity with almost all the strains.
\end{abstract}

Keywords: Thienopyrimidne; synthesis; antibacterial; antifungal; triazine. @2021 ACG Publication. All right reserved.

\section{Introduction}

The building of new heterocyclic compounds containing nitrogen and sulfur atoms attracts the interest of many organic chemists due to their biological importance in various aspects ${ }^{1,2}$. Among heterocyclic compounds containing nitrogen and sulfur, thienopyrimidines play an important role in the drug research as a result of strong biological activity they exhibit ${ }^{3-5}$ which may be attributed to the combination of thiophene and pyrimidine moieties which lead to potential bioactive molecules as they bear structural analogs and isoelectronic relations to purines ${ }^{6,7}$.

Moreover, fused bioactive thienopyrimidine heterocycle is a versatile lead molecule finding many applications in the pharmaceutical field exhibiting a broad spectrum of activities such as antimicrobial ${ }^{8-10}$,

\footnotetext{
* Corresponding author: E-Mail: mahmoud.tolba@ sci.nvu.edu.eg Phone: +201027297981

\#These authors (M S. Tolba and M. Sayed) contributed equally to this manuscript. 
Synthesis and biological activity of thienopyrimidines

antimalarial $^{11-13}$, antiviral ${ }^{14}$, analgesic ${ }^{15,16}$, antioxidant ${ }^{17,18}$, anticancer ${ }^{9,19-21}$, anti-inflammatory ${ }^{22-24}$, antihypertensive ${ }^{25}$, anti-histaminic ${ }^{24}$, antiproliferative ${ }^{26,27}$, anticovalent ${ }^{28}$, antihyperlipidemic ${ }^{29,30}$, and anticancer activity ${ }^{31-34}$.

Thienopyrimidine derivatives are considered good antimicrobial analog from the aspect of therapeutic activity ${ }^{35}$. Purines and pyrimidines derivatives make up the two groups of nitrogenos bases, including the two groups of nucleotide bases. These nucleotides are DNA and RNA building blocks, respectively. They also play an important role in many metabolic processes as potential nucleic acid antimetabolites ${ }^{36}$.

Although the antimicrobial activity of thienopyrimidines has been extensively studied, the mode of action is still challengeable, a report has been conducted to study the mechanism of activity for some selected thienopyrimidines against different strains of microorganism ${ }^{37}$. Due to the versatile biological activity of thienopyrimidines and in continuation to our work in this research area ${ }^{38-60}$, we report here a simple synthetic approach for the synthesis of some new thienopyrimidnes fused to triazine and other moieties as well as the screening of their antimicrobial activity.

\section{Experimental}

\subsection{General}

All melting points are uncorrected and measured on a Fisher-John apparatus. Elemental analyses $(\mathrm{C}, \mathrm{H}, \mathrm{N}$, and $\mathrm{S}$ ) were determined on an elemental analysis system GmbH-Vario EL V2.3 micro-analyzer in the central lab of Assiut University. The results were found to be in good agreement $( \pm 0.3 \%)$ with the calculated values. IR spectra were recorded on a Pye-Unicam Sp-100 spectrophotometer using the $\mathrm{KBr}$ wafer technique and values represented in $\mathrm{cm}^{-1} .{ }^{1} \mathrm{H}$ NMR and ${ }^{13} \mathrm{C}$ NMR were carried out on Varian Gemini $300 \mathrm{MHz}$ spectrophotometer at the Microanalytical Center, Cairo University, Cairo, Egypt, using tetramethylsilane (TMS) as an internal standard in deuterated dimethyl sulfoxide (DMSO-d6), and deuterated chloroform $\left(\mathrm{CDCl}_{3}\right)$ and the chemical shifts were recorded in ppm $\delta$ scale. The electron impact (EI) mass spectra were recorded on JEOL JMS- 600 spectrometer at central unit for analyse and scientific service, National Research Center, Cairo, Egypt. Analytical thin-layer chromatography (TLC) was carried out on silica gel plates (Fluka 70643-50EA. Sigma-Aldrich, Germany) using UV light. All reactions were carried out under an air atmosphere. The structures of all synthesized compounds were drowned and named using computer Chem Draw professional 13.0. Compound 1 was prepared according to literature procedure $^{38}$ and compound $\mathbf{2}$ was also synthesized according to our reported procedure ${ }^{45}$.

\subsection{Procedures for the Synthesis of Proposed Compounds}

9-Phenyl-4-phenylamino-7-(p-tolylamino)pyrimido[5',4':4,5]thieno[3,2-d] [1,2,3]triazine (3a): A mixture of compound $2(0.25 \mathrm{~g}, 6.17 \mathrm{mmol})$ and aniline $(2 \mathrm{mmol})$ was gently fused for $5 \mathrm{~min}$. then ethanol $(10 \mathrm{~mL})$ was added. The mixture was refluxed for $4 \mathrm{~h}$. The solid precipitate which formed during reflux was filtered, dried and recrystallized from ethanol as yellow crystals in $75 \%$ yield; mp 234-236 ${ }^{\circ} \mathrm{C}$. IR (KBr): vmax $\left(\mathrm{cm}^{-1}\right)$ 3341, $3316(2 \mathrm{NH}), 1618(\mathrm{C}=\mathrm{N}) .{ }^{1} \mathrm{H}$ NMR (300 MHz, DMSO-d $)$ ): $2.33\left(\mathrm{~s}, 3 \mathrm{H}, \mathrm{CH}_{3}\right), 6.90-7.75(\mathrm{~m}$, $14 \mathrm{H}, 3 \mathrm{ArH}), 9.26$ (s, $1 \mathrm{H}, \mathrm{NH}), 9.88(\mathrm{~s}, 1 \mathrm{H}, \mathrm{NH})$. Anal. Calcd. For: $\mathrm{C}_{26} \mathrm{H}_{19} \mathrm{~N}_{7} \mathrm{~S}$ (461.55): C, 67.66; H, 4.15; N, 21.24; S, $6.95 \%$. Found: C, 67.63; H, 4.18; N, 21.21; S, $6.98 \%$.

9-Phenyl-4,7-di-p-tolylamino-pyrimido[5',4':4,5]thieno[3,2-d][1,2,3]triazine $(\mathbf{3 b}):$ A mixture of compound $2(0.25 \mathrm{~g}, 6.17 \mathrm{mmol})$ and $p$-toluidine $(2 \mathrm{mmol})$ was gently fused for $5 \mathrm{~min}$. then ethanol (10 $\mathrm{mL}$ ) was added. The mixture was refluxed for $3 \mathrm{~h}$. The solid precipitate which formed during reflux was filtered, dried and recrystallized from ethanol to give buff fine in $92 \%$ yield; mp $244-246{ }^{\circ} \mathrm{C}$. IR ( $\mathrm{KBr}$ ): vmax $\left(\mathrm{cm}^{-1}\right) 3461,3339(2 \mathrm{NH}), 3050$ (CH aromatic), 2918, $2865\left(\mathrm{C} \mathrm{H}\right.$ aliphatic), $1592(\mathrm{C}=\mathrm{N}) .{ }^{1} \mathrm{H}$ NMR (300 MHz, $\left.\mathrm{CDCl}_{3}\right): 2.32\left(\mathrm{~s}, 6 \mathrm{H}, 2 \mathrm{CH}_{3}\right), 6.90-7.75(\mathrm{~m}, 13 \mathrm{H}, 3 \mathrm{ArH}), 9.33(\mathrm{~s}, 1 \mathrm{H}, \mathrm{NH}), 10.05(\mathrm{~s}, 1 \mathrm{H}, \mathrm{NH})$. Anal. Calcd. For: $\mathrm{C}_{27} \mathrm{H}_{21} \mathrm{~N}_{7} \mathrm{~S}$ (475.57): C, 68.19; H, 4.45; N, 20.62; S, 6.74\%. Found: $\mathrm{C}, 68.16 ; \mathrm{H}, 4.42$; $\mathrm{N}, 20.59 ; \mathrm{S}, 6.71 \%$. 
Tolba et al., Org. Commun. (2021) 14:4 365-376

9-Phenyl-4-(piperidin-1-yl)-7-(p-tolylamino)pyrimido[5',4':4,5]thieno[3,2-d] [1,2,3]triazine (4a) : A mixture of compound $2(0.25 \mathrm{~g}, 6.17 \mathrm{mmol})$ and piperidine $(2 \mathrm{mmol})$ was gently fused for $10 \mathrm{~min}$. then ethanol $(10 \mathrm{~mL})$ was added. The mixture was refluxed for $3 \mathrm{~h}$. The solid precipitate which formed during reflux was filtered, dried and recrystallized from dioxane-water (2:1) as faint brown crystals in $66 \%$ yield; mp 198-200 ${ }^{\circ} \mathrm{C}$. IR (KBr): vmax $\left(\mathrm{cm}^{-1}\right) 3138(\mathrm{NH}), 3061,3019(\mathrm{CH}$ aromatic), 2922, 2851 (C H aliphatic), $1612(\mathrm{C}=\mathrm{N}) .{ }^{1} \mathrm{H} \mathrm{NMR}\left(300 \mathrm{MHz}, \mathrm{CDCl}_{3}\right): 1.65\left(\mathrm{~m}, 2 \mathrm{H}, \mathrm{CH}_{2}\right), 1.68\left(\mathrm{~m}, 4 \mathrm{H}, 2 \mathrm{CH}_{2}-\mathrm{CH}_{2}\right), 2.33\left(\mathrm{~s}, 3 \mathrm{H}, \mathrm{CH}_{3}\right)$, $3.30,3.55$ (quasi d, $\left.J=3.6 \mathrm{~Hz}, 4 \mathrm{H}, 2 \mathrm{CH}_{2}-\mathrm{N}\right), 6.90-7.65(\mathrm{~m}, 9 \mathrm{H}, 2 \mathrm{ArH}), 10.28(\mathrm{~s}, 1 \mathrm{H}, \mathrm{NH}) .{ }^{13} \mathrm{C} \mathrm{NMR}(75.4$ $\mathrm{MHz} \mathrm{CDCl}_{3}$ 21.2, 32.6, 37.4, 59.0, 106.2, 122.2, 127.1, 128.6, 129.6, 132.99 ,133.8, 136.5, 139.0, 141.8, 151.7, 158.6, 168.2,172.7. Anal. Calcd. For: $\mathrm{C}_{25} \mathrm{H}_{23} \mathrm{~N}_{7} \mathrm{~S}$ (453.57): C, 66.20; H, 5.11; N, 21.62; S, 7.07\%. Found: C, 66.25; H, 5.14; N, 21.58; S, 7.04\%.

4-(Morpholino-1-yl)-9-phenyl-7-(p-tolylamino)pyrimido[5',4':4,5]thieno[3,2-d] [1,2,3]triazine (4b) : A mixture of compound $2(0.25 \mathrm{~g}, 6.17 \mathrm{mmol})$ and morpholine $(2 \mathrm{mmol})$ was gently fused for $10 \mathrm{~min}$. then ethanol $(10 \mathrm{~mL})$ was added. The mixture was refluxed for $4 \mathrm{~h}$. The solid precipitate which formed during reflux was filtered, dried and recrystallized from dioxane as brown in $56 \%$ yield; $\mathrm{mp} 228-230{ }^{\circ} \mathrm{C}$. IR ( $\left.\mathrm{KBr}\right)$ : $v\left(\mathrm{~cm}^{-1}\right) 3328(\mathrm{NH}), 2976,2921$ (C H aliphatic), $1587(\mathrm{C}=\mathrm{N}) .{ }^{1} \mathrm{H}$ NMR (300 MHz, $\left.\mathrm{CDCl}_{3}\right): 2.32(\mathrm{~s}, 3 \mathrm{H}$, $\mathrm{CH}_{3}$ ), 3.45-3.60 (quasi d, J=3.9 Hz, $4 \mathrm{H}, 2 \mathrm{CH}_{2}-\mathrm{N}$ ), 3.78-4.08 (quasi d, 4.0 Hz, 4H, 2CH $\mathrm{CH}_{2}-\mathrm{O}$ ), 6.87-7.70 (m, $9 \mathrm{H}, 2 \mathrm{ArH}), 10.37$ (s, $1 \mathrm{H}, \mathrm{NH})$. Anal. Calcd. For: $\mathrm{C}_{24} \mathrm{H}_{21} \mathrm{~N}_{7} \mathrm{OS}$ (455.54): C, 63.28; H, 4.65; N, 21.52; S, 7.04\%. Found: C, 63.25; H, 4.68; N, 21.48; S, 7.08\%.

4-((9-phenyl-7-(p-tolylamino)pyrimido[5',4':4,5]thieno[3,2-d][1,2,3]triazin-4-

$y l$ )amino)benzenesulfonamide (5a) : A mixture of compound $2(0.25 \mathrm{~g}, 6.17 \mathrm{mmol})$ and sulfanilamide (2 $\mathrm{mmol})$ was gently fused for $5 \mathrm{~min}$. Then ethanol $(10 \mathrm{~mL})$ was added. The mixture was refluxed for $3 \mathrm{~h}$. The resultant solid product was filtered, washed with water, dried and recrystallized from ethanol as white crystals in 76\% yield; mp 138-140 ${ }^{\circ} \mathrm{C}$. IR $(\mathrm{KBr}): v\left(\mathrm{~cm}^{-1}\right) 3330,3217,\left(2 \mathrm{NH}, \mathrm{NH}_{2}\right), 3080(\mathrm{CH}$ aromatic), 2923 (CH aliphatic), $1642(\mathrm{C}=\mathrm{N}), 1444\left(\mathrm{SO}_{2} \mathrm{NH}\right) .{ }^{1} \mathrm{H}$ NMR (300 MHz, DMSO-d $)$ : $2.32\left(\mathrm{~s}, 3 \mathrm{H}, \mathrm{CH}_{3}\right), 6.89-$ $7.85(\mathrm{~m}, 13 \mathrm{H}, 3 \mathrm{ArH}), 8.49\left(\mathrm{~s}, 2 \mathrm{H}, \mathrm{NH}_{2}\right), 9.71(\mathrm{~s}, 1 \mathrm{H}, \mathrm{NH}), 10.46(\mathrm{~s}, 1 \mathrm{H}, \mathrm{NH}) \mathrm{ppm}$. Anal. Calcd. For: $\mathrm{C}_{26} \mathrm{H}_{20} \mathrm{~N}_{8} \mathrm{O}_{2} \mathrm{~S}_{2}$ (540.62): C, 57.76; H, 3.73; N, 20.73; S, $11.86 \%$. Found: C, 57.73; H, 3.76; N, 20.71; S, $11.83 \%$.

$N$-Carbamimidoyl-4-((9-phenyl-7-(p-tolylamino)pyrimido[5',4':4,5]thieno[3,2-d] [1,2,3]triazin-4yl)amino)benzenesulfonamide (5b) : A mixture of compound $2(0.25 \mathrm{~g}, 6.17 \mathrm{mmol})$ and sulphaguanidine $(2 \mathrm{mmol})$ was gently fused for $5 \mathrm{~min}$. Then ethanol $(10 \mathrm{~mL})$ was added. The mixture was refluxed for $4 \mathrm{~h}$. The resultant solid product was filtered, washed with water, dried and recrystallized from ethanol as white crystals in $75 \%$ yield; mp 266-268 ${ }^{\circ} \mathrm{C}$. IR $(\mathrm{KBr}): v\left(\mathrm{~cm}^{-1}\right) 3469,3297,3256,3157\left(\mathrm{NH}_{2}, 4 \mathrm{NH}\right), 2998(\mathrm{C} \mathrm{H}$ aliphatic), $1607(\mathrm{C}=\mathrm{N}), 1333\left(\mathrm{SO}_{2} \mathrm{NH}\right) .{ }^{1} \mathrm{H}$ NMR (300 MHz, DMSO-d 6$): 2.32\left(\mathrm{~s}, 3 \mathrm{H}, \mathrm{CH}_{3}\right), 2.95(\mathrm{~s}, 1 \mathrm{H}$, $\mathrm{NH}), 6.29\left(\mathrm{~s}, 2 \mathrm{H}, \mathrm{NH}_{2}\right), 6.85-7.93(\mathrm{~m}, 13 \mathrm{H}, 3 \mathrm{Ar}-\mathrm{H}), 8.69(\mathrm{~s}, 1 \mathrm{H}, \mathrm{NH}), 9.42(\mathrm{~s}, 1 \mathrm{H}, \mathrm{NH}), 10.17(\mathrm{~s}, 1 \mathrm{H}, \mathrm{NH})$. ${ }^{13} \mathrm{C}$ NMR (75.4 MHz, DMSO-d ${ }_{6}$ ): 21.1, 116.0, 124.0, 126.22, 128.6, 129.7, 142.3, 119.8, 129.4, 131.3, 134.3, 136.6, 144.4, 147.2, 149.4, 152.3, 154.7, 155.4, 159.9, 174.7. MS (m/z): 582.25 (M+,98\%). Anal. Calcd. For: $\mathrm{C}_{27} \mathrm{H}_{22} \mathrm{~N}_{10} \mathrm{O}_{2} \mathrm{~S}_{2}$ (582.66): C, 55.66; H, 3.81; N, 24.04; S, 11.00. Found: 55.69; H, 3.78; N, 24.07; $\mathrm{S}, 11.04 \%$.

N-[7-p-tolylamino-9-phenylpyrimido[5',4':4,5]thieno[3,2-d]triazine-4-yl]-sulfathiazole $\quad(\mathbf{5 c}) \quad: \quad$ To a solution of compound $2(0.25 \mathrm{~g}, 6.17 \mathrm{mmol})$ and sulphathiazole $(2 \mathrm{mmol})$ was gently fused for $5 \mathrm{~min}$. Then ethanol $(10 \mathrm{~mL})$ was added. The mixture was refluxed for $4 \mathrm{~h}$. The solid product thus formed was filtered, washed with water, dried and recrystallized from dioxane: ethanol mixture $(2: 1)$ as brown crystals in $56 \%$ yield; mp 203-205 ${ }^{\circ} \mathrm{C}$. IR (KBr): $v\left(\mathrm{~cm}^{-1}\right) 3384(3 \mathrm{NH}), 3060$ ( $\mathrm{CH}$ aromatic), 2923, 2852 (CH aliphatic), $1593(\mathrm{C}=\mathrm{N}), 1404\left(\mathrm{SO}_{2} \mathrm{NH}\right) .{ }^{1} \mathrm{H}$ NMR $\left(300 \mathrm{MHz}, \mathrm{DMSO}-\mathrm{d}_{6}\right): 2.32\left(\mathrm{~s}, 3 \mathrm{H}, \mathrm{CH}_{3}\right), 6.00(\mathrm{~s}, 1 \mathrm{H}, \mathrm{NH}), 6.87$, $6,89(\mathrm{~s}, 2 \mathrm{H}, 2 \mathrm{CH}$ thioazole $), 7.06-7.86(\mathrm{~m}, 13 \mathrm{H}, 3 \mathrm{ArH}), 9.06(\mathrm{~s}, 1 \mathrm{H}, \mathrm{NH})$ and $10.50(\mathrm{~s}, 1 \mathrm{H}, \mathrm{NH}) .{ }^{13} \mathrm{C}$ NMR (75.4 MHz, DMSO-d 6 ): 21.4, 107.9, 114.2, 116.8, 122.9, 124.43, 127.8, 130.6, 132.4, 134.8, 136.3, 137.5, 140.6, 145.7, 147.7, 152.4, 156.8, 158.9,174.1, 177.9. MS (m/z): 623.12 (M+, $97.56 \%)$. Anal. Calcd. For: $\mathrm{C}_{29} \mathrm{H}_{21} \mathrm{~N}_{9} \mathrm{O}_{2} \mathrm{~S}_{3}$ (623.73): C, 55.84; H, 3.39; N, 20.21; S, $15.42 \%$. Found: C, 55.87; H, 3.35; N, 20.24; S, $15.39 \%$. 
Synthesis and biological activity of thienopyrimidines

9-Phenyl-7-(p-tolylamino)pyrimido[4',5':4,5]thieno[2,3-d]pyrimidine-2,4(1H,3H)-dithione (6) :

Compound $2(1.0 \mathrm{~g}, 2.79 \mathrm{mmol})$ was dissolved in $10 \%$ alcoholic sodium hydroxide solution $(5 \mathrm{~mL})$, and then refluxed with excess carbon disulphide on a water bath for $8 \mathrm{~h}$. During the reflux time fresh carbon disulphide was added (two times), and then the product was separated, collected by filtration, and recrystallized from acetic acid as deep red crystals in $79 \%$ yield; $m p>360{ }^{\circ} \mathrm{C}$. IR $(\mathrm{KBr}): v\left(\mathrm{~cm}^{-1}\right) 3475$, 3406 and $3313(3 \mathrm{NH}), 1643(\mathrm{C}=\mathrm{N}) .{ }^{1} \mathrm{H}$ NMR $\left(300 \mathrm{MHz}, \mathrm{DMSO}-\mathrm{d}_{6}\right): 2.33$ (s, 3H, CH3), 6.92-7.63 (m, 9H, 2Ar-H), 8.79 (s, $1 \mathrm{H}, \mathrm{NH}), 9.87(\mathrm{~s}, 1 \mathrm{H}, \mathrm{NH}), 11.16(\mathrm{~s}, 1 \mathrm{H}, \mathrm{NH})$. Anal. Calcd. For: $\mathrm{C}_{21} \mathrm{H}_{15} \mathrm{~N}_{5} \mathrm{~S}_{3}$ (433.57): C, 58.18; H, 3.49; N, 16.15; S, 22.18\%. Found: C, 58.14; H, 3.45; N, 16.12; S, $22.23 \%$.

\section{Diethyl2,2'-((9-phenyl-7-(p-tolylamino)pyrimido[4',5':4,5]thieno[2,3-d]pyrimidine-2,4-diyl)}

bis(sulfanediyl))diacetate (7) : Compound $6(0.5 \mathrm{~g}, 1.15 \mathrm{mmol})$ was refluxed with ethyl chloroacetate (2 $\mathrm{mL}, 18 \mathrm{mmol})$ in ethanol $(20 \mathrm{~mL})$ in the presence of anhydrous sodium acetate $(2.0 \mathrm{~g})$ for $2 \mathrm{~h}$. The color of the reaction mixture changed from red to brown, then the brown product was precipitated, collected by filtration, and recrystallized from dioxane-ethanol mixture (2:1) as deep brown crystals in $63 \%$ yield; mp 198-200 ${ }^{\circ} \mathrm{C}$. IR (KBr): $v\left(\mathrm{~cm}^{-1}\right) 3365(\mathrm{NH}), 2974,2929\left(\mathrm{C} \mathrm{H}\right.$ aliphatic), 1671(2CO ester), $1607(\mathrm{C}=\mathrm{N}) .{ }^{1} \mathrm{H}$ NMR (300 MHz, CDCl $): 1.36\left(\mathrm{t}, J=4.7 \mathrm{~Hz}, 3 \mathrm{H}, \mathrm{CH}_{3}\right), 1.39\left(\mathrm{t}, J=4.7 \mathrm{~Hz}, 3 \mathrm{H}, \mathrm{CH}_{3}\right), 2.32\left(\mathrm{~s}, 3 \mathrm{H}, \mathrm{CH}_{3}\right)$, 3.96 (s, 2H, $\left.\mathrm{CH}_{2}\right), 4.00$ (s, 2H, CH$)_{2}, 4.14$ (q, J=4.7 Hz, 2H, $\mathrm{CH}_{2}$ ), 4.19 (q, J=4.7 Hz, 2H, CH (m, 9H, 2Ar-H), 9.59 (s, 1H, NH). Anal. Calcd. For $\mathrm{C}_{29} \mathrm{H}_{27} \mathrm{~N}_{5} \mathrm{O}_{4} \mathrm{~S}_{3}$ (605.75): C, 57.50; H, 4.49; N, 11.56; S, 15.88. Found: C, 57.54; H, 4.53; N, 11.52; S, $15.92 \%$.

\section{4-Imino-3,9-diphenyl-7-(p-tolylamino)-3,4-dihydropyrimido[4',5':4,5]thieno}

[2,3-d]pyrimidine-2(1H)-thione $(8)$ : Compound $2(1.0 \mathrm{~g}, 2.79 \mathrm{mmol})$ was dissolved in pyridine $(5 \mathrm{~mL})$, phenyl isothiocyanate $(0.4 \mathrm{~mL}, 30 \mathrm{mmol})$ was added to the above solution. The reaction mixture was refluxed for $6 \mathrm{~h}$, and then cooled, where by reddish brown crystals were separated out, collected by filtration, dried and recrystallized from ethanol in $63 \%$ yield; mp 198-200 ${ }^{\circ} \mathrm{C}$. IR (KBr): vmax (cm-1) 3433 , 3317 (3NH), 2983 (C H aliphatic), $1626(\mathrm{C}=\mathrm{N}), 1212(\mathrm{C}=\mathrm{S}) .{ }^{1} \mathrm{H}$ NMR (300 MHz, DMSO-d 6 ): 2.32 (s, 3H, $\left.\mathrm{CH}_{3}\right)$, 6.89-7.66 (m, 14H, 3Ar-H), 7.01 (s, $\left.1 \mathrm{H}, \mathrm{NH}\right), 9.50(\mathrm{~s}, 1 \mathrm{H}, \mathrm{NH}), 10.71(\mathrm{~s}, 1 \mathrm{H}, \mathrm{NH})$. Anal. Calcd. For: $\mathrm{C}_{27} \mathrm{H}_{20} \mathrm{~N}_{6} \mathrm{~S}_{2}$ (492.62): C, 65.83; H, 4.09; N, 17.06; S, 13.02\%. Found: C, 65.80; H, 4.05; N, 17.09; S, 13.05 $\%$.

5-(Diacetylamino)-(6-cyano-4-phenyl-2-(p-tolylamino)thieno[2,3-d]pyrimidine (9) : Compound 2 (0.5 g, $1.39 \mathrm{mmol}$ ) was refluxed with acetic anhydride $(5 \mathrm{~mL})$ for $3 \mathrm{~h}$. The reaction mixture was cooled and then poured into cold water $(100 \mathrm{~mL})$, and then the product was precipitated, collected and recrystallized from benzene as yellow needles in $63 \%$ yield; mp 174-176 ${ }^{\circ} \mathrm{C}$. IR (KBr): $v\left(\mathrm{~cm}^{-1}\right) 3199(\mathrm{NH}), 2921(\mathrm{CH}$ aliphatic), $2216(\mathrm{CN}), 1676(2 \mathrm{CO}), 1577(\mathrm{C}=\mathrm{N}) .{ }^{1} \mathrm{H}$ NMR (300 MHz, $\left.\mathrm{CDCl}_{3}\right): 2.33\left(\mathrm{~s}, 3 \mathrm{H}, \mathrm{CH}_{3}\right), 2.37(\mathrm{~s}$, $\left.6 \mathrm{H}, 2 \mathrm{CH}_{3}\right), 6.91-7.67(\mathrm{~m}, 9 \mathrm{H}, 2 \mathrm{Ar}-\mathrm{H}), 10.37$ (s, $\left.1 \mathrm{H}, \mathrm{NH}\right)$. Anal. Calcd. For $\mathrm{C}_{24} \mathrm{H}_{19} \mathrm{~N}_{5} \mathrm{O}_{2} \mathrm{~S}$ (441.51): C, 65.29; H, 4.34; N, 15.86; S, 7.26\%. Found: C, 65.33; H, 4.37; N, 15.89; S, $7.29 \%$.

\subsection{Antimicrobial Activities and Minimum Inhibitory Concentration (MIC)}

All the new synthesized compounds listed in Tables 1 and 2 were screened for their in vitro antimicrobial activity against model Gram-positive (B. cereus and S. aureus) and Gram-negative bacteria ( $P$. aruginose, and E. coli). The antimicrobial activity and MIC were determined by the agar diffusion assay using the filter paper disc method ${ }^{61}$. The MICs of the synthesized compounds were determined against Gram-positive and Gram-negative bacteria and pathogenic fungi (Geotrichum candidum, Candida albicans, Trichophyton rubrum, and Aspergillus flavus). It was carried out by impregnation of different concentrations of synthesized compounds $(50,100,150,200 \mu \mathrm{g} / \mathrm{mL})$ in DMSO as a solvent and placed on filter paper discs $(5 \mathrm{~mm})$. Nutrient agar and Sabouraud's dextrose agar media were used for the inoculation of bacteria and fungi, respectively. Standard antibiotic discs (Amoxicillin $50 \mathrm{mg}$, and fluconazole $50 \mathrm{mg}$ ) and blank discs (impregnated with DMSO) were used as positive and negative control. The plates were then incubated at $37^{\circ} \mathrm{C}$ for $24 \mathrm{hr}$. for bacteria and $25{ }^{\circ} \mathrm{C}$ for 6 days for fungi. The zones of inhibition were measured in $\mathrm{mm}$ and recorded. The lowest concentration that inhibited the growth of the test organisms was recorded as the MIC. The biological activity as expressed by the growth inhibition zone 
Tolba et al., Org. Commun. (2021) 14:4 365-376

of the tested microorganism is listed in Tables 1and 2 and Figure S1 and Figure S2 in supporting information. The MICs were recorded.

\section{Results and Discussion}

\subsection{Chemistry}

Diazotization of the bifunctionalized amino carbonitrile compound $\mathbf{1}$ with sodium nitrite solution $(10 \%)$ in the presence of a mixture of acetic acid and conc. $\mathrm{HCl}$ at room temperature was afforded the newly synthesized 4-chloro-9-phenyl-7-(p-tolylamino)pyrimido[5',4':4,5]thieno[3,2-d][1,2,3]triazine (2). The chemical structure of compound 2 was confirmed based on the elemental and spectral data. Its IR and ${ }^{1} \mathrm{H}$ NMR spectra declared the disappearance of absorption bands at 3477,3387 , and $2187 \mathrm{~cm}^{-1}$ for $\mathrm{NH}_{2}$ and $\mathrm{CN}$ groups in the starting material, the appearance of a new absorption band at $1600 \mathrm{~cm}^{-1}$ for $\mathrm{C}=\mathrm{N}$ group, in addition to the disappearance of the singlet signal at $\delta 6.44 \mathrm{ppm}$ for $\mathrm{NH}_{2}$ in the ${ }^{1} \mathrm{H}$ NMR spectra. The chlorine atom in compound $\mathbf{2}$ underwent nucleophilic substitution reactions with various primary and secondary amines gave the corresponding $N$-substituted pyrimidothienotriazine derivatives (3-5).

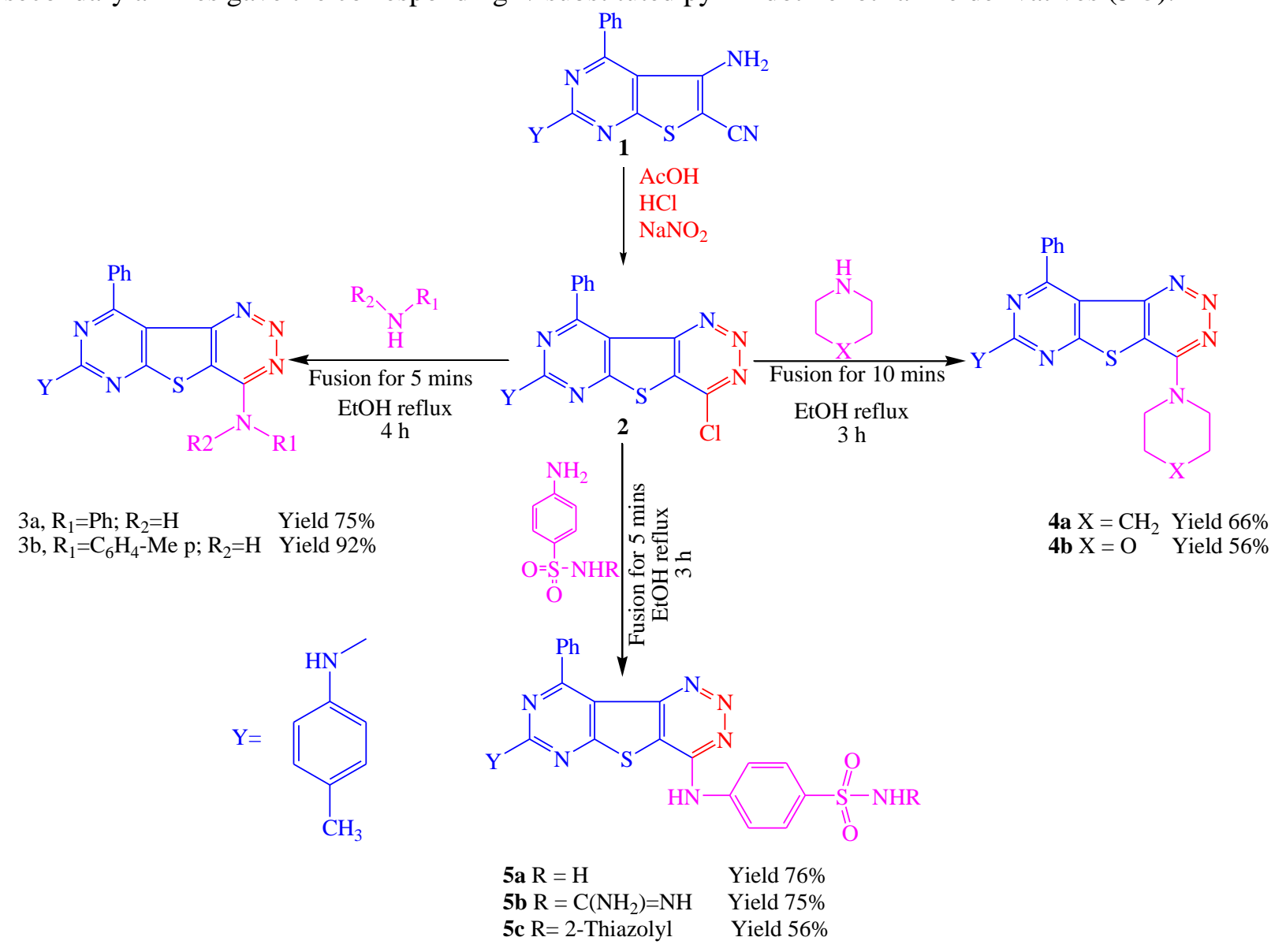

Scheme 1. Synthesis of triazine fused thienopyrimidine derivatives

Assignment of the chemical structures of the new compounds (3-5) was elucidated from their elemental and spectral analyses. The IR spectrum of compound 3a showed two absorption bands at 3341 and $3316 \mathrm{~cm}^{-1}$ for $\mathrm{NH}$ groups. ${ }^{1} \mathrm{H}$ NMR spectrum of compound 3a showed two singlet signals at $\delta 9.26$ and $9.88 \mathrm{ppm}$ for $2 \mathrm{NH}$ groups. In addition, the IR spectrum of piperidinyl compound 4a showed new absorption bands at $3138,3081,2922$, and $2851 \mathrm{~cm}^{-1}$ for $\mathrm{NH}, \mathrm{CH}$ aromatic, and $\mathrm{CH}$ aliphatic groups respectively. ${ }^{1} \mathrm{H}$ NMR spectrum presented multiplet signals at $\delta 1.65-1.68 \mathrm{ppm}$ for $3 \mathrm{CH}_{2}$ aliphatic protons and triplet signals at $\delta 3.30 \mathrm{ppm}$ characteristic of $2 \mathrm{CH}_{2}$ aliphatic. In addition, the ${ }^{13} \mathrm{C}$ NMR spectrum of 
Synthesis and biological activity of thienopyrimidines

compound 4a showed signals at $\delta 32.56,37.45$, and 58.98 ppm for $5 \mathrm{CH}_{2}$ groups respectively. Furthermore, the IR spectrum of benzenesulfonamide derivative $\mathbf{5 c}$ revealed a broad absorption band at $3384 \mathrm{~cm}^{-1}$ for $\mathrm{NH}$ groups and an absorption band at $1403 \mathrm{~cm}-1$ for the $\mathrm{SO}_{2}$ group. $1 \mathrm{H}$ NMR spectrum revealed three singlet signals at $\delta 6.00,9.60$, and $10.50 \mathrm{ppm}$ which attributed to $\mathrm{NH}$ groups. ${ }^{13} \mathrm{C}$ NMR spectrum showed the appearance of signals at $\delta 114.18,137.49$, and 177.87 for the carbon atom of the thiazolyl ring.<smiles>[X]c1nc(-c2ccccc2)c2c(n1)sc1c(SCC(=O)OCC)nc(SCC(=O)OCC)nc12</smiles>

7 Yield 63\%<smiles>CNc1ccc(C)cc1</smiles><smiles>[Y]c1nc(-c2ccccc2)c2c(n1)sc1c(=S)[nH]c(=S)[nH]c12</smiles>

6 Yield $79 \%$<smiles>[Y]c1nc(-c2ccccc2)c2c(n1)S(C)(C)C(C#N)=C2N</smiles><smiles>[Y]c1nc(-c2ccccc2)c2c(n1)sc1c(N=C=S)nc(=S)[nH]c12</smiles>

8 Yield $63 \%$<smiles>[Y]c1nc(-c2ccccc2)c2c(N([14CH3])C(C)=O)c(C#N)sc2n1</smiles>

9 Yield $63 \%$

Scheme 2. Synthesis of pyrimidothienopyrimidine derivatives

Reaction of 5-amino-4-phenyl-2-(p-tolylamino)thieno[2,3-d]pyrimidine-6-carbonitrile (1) with carbon disulfide in pyridine on a steam bath yielded the corresponding 9-phenyl-7-( $p$ tolylamino)pyrimido[4',5':4,5]thieno[2,3- $d$ ]pyrimidine-2,4(1H, 3H)-dithione (6) which on subsequent alkylation with ethylchloro acetate afforded 2,4-bis(ethylacetatemercapto)-9-phenyl-7-( $p$ tolylamino)pyrimido[4',5':4,5]thieno[2,3- $d]$ pyrimidine (7). The chemical structures of compounds $(\mathbf{6}, \mathbf{7})$ were elucidated by the elemental and the spectral analyses, the IR spectrum of the dithione compound $\mathbf{6}$ showed absorption bands at $3475,3406,3313$, and $1176 \mathrm{~cm}^{-1}$ characteristic of $\mathrm{NH}$ and $\mathrm{C}=\mathrm{S}$ groups respectively. IR spectrum of compound 7 revealed the appearance of absorption bands at 3365 and 1671 $\mathrm{cm}^{-1}$ characteristic of $\mathrm{NH}$ and $\mathrm{CO}$ ester groups respectively. In addition to the ${ }^{1} \mathrm{H}$ NMR spectrum of compound 6 stated the presence of three singlet signals at $\delta 8.79,9.87$, and $11.16 \mathrm{ppm}$ characteristic of $\mathrm{NH}$ groups. The ${ }^{1} \mathrm{H}$ NMR spectrum of compound 7 showed triplet and quartet signals characteristic of $\mathrm{CH}_{3}$ and $\mathrm{CH}_{2}$ groups of ester at $\delta 1.36,1.39,4.14$ and $4.19 \mathrm{ppm}$. In addition, the presence of two singlet signals at $\delta$ 3.96 and $4.00 \mathrm{ppm}$ for $2 \mathrm{CH}_{2}$ groups. Compound 1 was reacted with phenyl isothiocyanate in pyridine to 
Tolba et al., Org. Commun. (2021) 14:4 365-376

afford 9-phenyl-4-(phenylamino)-7-(p-tolylamino)pyrimido[4',5':4,5]thieno $[2,3-d]$ pyrimidine-2(1H)thione (8). In addition, reaction of compound 1 with acetic anhydride afford 5-diacetylamino-4-phenyl-2( $p$-tolylamino)thieno[2,3- $d$ ]pyrimidin-6-carbonitrile (9). The chemical structures of compounds $\mathbf{8}$, and $\mathbf{9}$ were elucidated by the elemental and spectral analyses, The IR spectrum of the iminothione compound $\mathbf{8}$ showed absorption bands at 3433, 3317, 1626, and $1212 \mathrm{~cm}^{-1}$ characteristic of $\mathrm{NH}, \mathrm{C}=\mathrm{N}$, and $\mathrm{C}=\mathrm{S}$ groups respectively. The IR spectrum of compound 9 revealed the presence of absorption bands at 3199, 2216, and $1676 \mathrm{~cm}^{-1}$ characteristic of $\mathrm{NH}, \mathrm{CN}$, and $\mathrm{CO}$ acetyl groups respectively. In addition, the ${ }^{1} \mathrm{H}$ NMR spectrum of compound $\mathbf{8}$ stated the presence of three singlet signals at $\delta 7.01,9.50$, and $10.74 \mathrm{ppm}$ characteristic of $\mathrm{NH}$ groups and multiple signals at $\delta 6.89-7.66 \mathrm{ppm}$ for 14 aromatic protons of 3 phenyl rings. ${ }^{1} \mathrm{H}$ NMR spectrum of compound 9 showed two singlet signals characteristic of two $\mathrm{CH}_{3}$ groups at $\delta 2.33$ and 2.37 ppm. In addition, the appearance of the singlet signal at $\delta 10.37 \mathrm{ppm}$ for $\mathrm{NH}$ groups.

\subsection{Antimicrobial and Antifungal Activities}

\subsubsection{Antibacterial Activity}

From the data presented in Table 1, it can be concluded that all the investigated compounds showed remarkable antibacterial activity against Gram-positive bacteria (Bacillus cereus, Staphylococcus aureus) and Gram-negative bacteria (Pseudomonas aruginose, Escherichia coli). From the inhibition zone values, compounds $\mathbf{3 b}, \mathbf{4 b}, \mathbf{5 c}, \mathbf{6}$, and $\mathbf{7}$ showed the highest antibacterial activity against almost all strains of bacteria, with values close to those of the corresponding reference antibiotics (Nitrofurantoin).

Table 1. Antibacterial activity of compounds (1-9)

\begin{tabular}{ccccc}
\hline No & B. cereus & S. aureus & P. aruginose & E. coli \\
\hline $\mathbf{1}$ & $12^{\mathrm{a}}(9.0)^{\mathrm{b}}$ & $14(8.0)$ & $12(9.0)$ & $13(11.0)$ \\
$\mathbf{2}$ & $17(9.0)$ & $16(8.0)$ & $17(8.0)$ & $17(8.0)$ \\
$\mathbf{3 a}$ & $18(8.0)$ & $17(7.0)$ & $19(8.0)$ & $18(8.0)$ \\
$\mathbf{3 b}$ & $20(0.7)$ & $19(7.0)$ & $18(8.0)$ & $19(7.0)$ \\
$\mathbf{4 a}$ & $16(8.0)$ & $13(8.0)$ & $18(7.0)$ & $18(8.0)$ \\
$\mathbf{4 b}$ & $20(0.7)$ & $19(8.0)$ & $13(9.0)$ & $14(8.0)$ \\
$\mathbf{5 a}$ & $15(9.0)$ & $11(10.0)$ & - & $12(9.0)$ \\
$\mathbf{5 b}$ & $17(9.0)$ & $16(9.0)$ & $19(8.0)$ & $15(8.0)$ \\
$\mathbf{5} \mathbf{c}$ & $19(8.0)$ & $16(8.0)$ & $14(7.0)$ & $17(8.0)$ \\
$\mathbf{6}$ & $19(8.0)$ & $17(9.0)$ & $19(7.0)$ & $19(8.0)$ \\
$\mathbf{7}$ & $20(0.7)$ & $15(8.0)$ & $18(7.0)$ & $19(8.0)$ \\
$\mathbf{8}$ & $16(0.8)$ & $13(9.0)$ & - & $14(8.0)$ \\
$\mathbf{9}$ & - & $14(8.0)$ & $16(8.0)$ & $15(8.0)$ \\
Nitrofurantoin & $26(5.0)$ & $25(4.0)$ & $24(3.0)$ & $20(0.5)$ \\
\hline
\end{tabular}

(a) Numbers out parentheses represent the dimer of inhibition zone in ( $\mathrm{mm}$ ) of compounds 1-9

(b) Numbers in parentheses represent the MIC (minimum inhibition concentration) in $(\mu \mathrm{g} / \mathrm{mL})$ of tested compounds

While compounds 5a and 9 showed the lowest antibacterial activity among all the tested compounds which suggested that the $\mathrm{SO}_{2} \mathrm{NH}_{2}$ group in 5a has a low effect on the bacteria strains, unlike compound $\mathbf{5 c}$ that exhibited strong activity which may be attributed to the existence of thiazolylsulfonyl moiety. Moreover, compounds $\mathbf{3 b}, \mathbf{4 b}$, and $\mathbf{7}$ displayed excellent activity against Bacillus cereus, while the inhibition of Staphylococcus aureus was achieved by compounds $\mathbf{3 b}$ and $\mathbf{4 b}$. Furthermore, compounds $\mathbf{2}$ and $\mathbf{6}$ demonstrated promising efficiency towards both gram-negative and gram-positive bacteria. In conclusion, the data obtained showed that the compound 9-phenyl-4,7-di-p-tolylaminopyrimido[ $\left[5^{\prime}, 4^{\prime}: 4,5\right]$ thieno[3,2- $\left.d\right][1,2,3]$ triazine $\mathbf{( 3 b )}$ containing pyrimidothienotriazine moiety with $p$-tolyl substituent and compound diethyl 2,2'-((9-phenyl-7-( $p$-tolylamino) pyrimido [4',5':4,5]thieno[2,3$d$ ]pyrimidine-2,4diyl)bis(sulfanediyl))diacetate (7) which has pyrimidothienopyrimidne moiety with two ethyl acetate substituent exhibited the highest antibacterial activity against all bacteria strains. To our 
Synthesis and biological activity of thienopyrimidines

delight that all the synthesized compounds showed antimicrobial activity higher than that of starting material which supports the utilization of this synthetic study.

\subsubsection{Antifungal Activity}

The antifungal activity results for all synthesized compounds against four fungal species are summarized in Table 2, the table shows that all the investigated compounds demonstrated remarkable antifungal activities against all the fungi (Geotrichum candidum, Candida albicans, Trichophyton rubrum, and Aspergillus flavus), the data showed that the compounds 9-phenyl-4,7-di-p-tolylaminopyrimido[5', $\left.4^{\prime}: 4,5\right]$ thieno[3,2- $\left.d\right][1,2,3]$ triazine (3b) and 9-phenyl-7-(ptolylamino)pyrimido[4',5':4,5] thieno[2,3-d]pyrimidine-2,4(1H,3H)-dithione $(\mathbf{6})$, have the highest antifungal activity against all the strains of fungi. From Tables $\mathbf{1}$ and 2, it could be stated that compounds $\mathbf{3 b}$ and $\mathbf{6}$ have antimicrobial activity against different strains of gram-positive, gram-negative bacteria, and fungi with values close to those of the corresponding standers. Furthermore, all the investigated compounds showed good activity higher than that of the precursor which suggests the importance of this study and reflects the effect of derivatization on the enhancement of biological activity.

Table 2. Antifungal activity of compounds (1-9)

\begin{tabular}{ccccc}
\hline No & $\begin{array}{c}\text { Geotrichum } \\
\text { candidium }\end{array}$ & $\begin{array}{c}\text { Candida } \\
\text { albicans }\end{array}$ & $\begin{array}{c}\text { Trichophyton } \\
\text { rubrum }\end{array}$ & $\begin{array}{c}\text { Aspergillus } \\
\text { flavus }\end{array}$ \\
\hline $\mathbf{1}$ & $12^{\mathrm{a}}(11.0)^{\mathrm{b}}$ & $13(10.0)$ & $14(9.0)$ & $14(10.0)$ \\
$\mathbf{2}$ & $14(10.0)$ & $13(8.0)$ & $13(9.0)$ & $17(10.0)$ \\
$\mathbf{3 a}$ & $16(8.0)$ & $16(8.0)$ & $16(7.0)$ & $18(9.0)$ \\
$\mathbf{3 b}$ & $18(8.0)$ & $17(8.0)$ & $22(7.0)$ & $19(9.0)$ \\
$\mathbf{4 a}$ & $15(7.0)$ & $17(8.0)$ & $17(8.0)$ & $16(8.0)$ \\
$\mathbf{4 b}$ & $12(8.0)$ & $14(8.0)$ & $15(9.0)$ & $14(9.0)$ \\
$\mathbf{5 a}$ & $14(8.0)$ & $17(7.0)$ & $15(9.0)$ & $12(9.0)$ \\
$\mathbf{5 b}$ & $12(7.0)$ & - & $14(9.0)$ & $17(8.0)$ \\
$\mathbf{5 c}$ & $15(7.0)$ & $13(8.0)$ & $11(8.0)$ & $14(8.0)$ \\
$\mathbf{6}$ & $18(7.0)$ & $19(8.0)$ & $17(9.0)$ & $18(9.0)$ \\
$\mathbf{7}$ & - & $13(8.0)$ & $15(9.0)$ & $16(8.0)$ \\
$\mathbf{8}$ & $15(10.0)$ & $11(7.0)$ & $17(9.0)$ & - \\
$\mathbf{9}$ & $17(10.0)$ & $16(7.0)$ & $10(9.0)$ & $17(9.0)$ \\
Clotrimazole & $20(4.0)$ & $23(5.0)$ & $28(4.0)$ & $22(5.0)$ \\
\hline
\end{tabular}

a) Numbers out parentheses represent the dimer of inhibition zone in ( $\mathrm{mm}$ ) of compounds 1-9

(b) Numbers in parentheses represent the MIC (minimum inhibition concentration) in $(\mu \mathrm{g} / \mathrm{mL})$ of tested compounds

\section{Conclusion}

To sum up, in this work we have successfully synthesized a series of new potent heterocyclic compounds containing thienopyrimidine moiety, different spectral analysis techniques have utilized to confirm the structures of the designed products. All compounds were in vitro investigated for their antibacterial as well as antifungal activities against different strains of bacteria and fungi showing moderate to high activity and the obtained MIC values and inhibition zones for some synthesized derivatives were shown values close to the used reference drug. In the future, we will focus on the development of different series of thienopyrimidne for the investigation of other pharmaceutical activities such as anticancer and antitumor.

\section{Supporting Information}

Supporting information accompanies this paper on http://www.acgpubs.org/journal/organiccommunications 
Tolba et al., Org. Commun. (2021) 14:4 365-376

\section{ORCID}

Mahmoud S. Tolba: 0000-0002-6720-7386

Mostafa Sayed: 0000-0002-5469-0129

Adel M. Kamal El-Dean: 0000-0003-1738-9860

Reda Hassanien: 0000-0003-2752-435X

Shaban A. A. Abdel-Raheem: 0000-0001-7422-1840

Mostafa Ahmed: 0000-0002-3264-9299

\section{References}

[1] Parveen, H.; Alatawi, R.A.S.; El Sayed, N.H.; Hasan, S.; Mukhtar, S.; Khan, A.U. Synthesis, characterization and biological evaluation of some novel nitrogen and sulphur containing organometallic heterocycles. Arab. J. Chem. 2017, 10, 1098-1106.

[2] Mermer, A.; Keles, T.; Sirin, Y. Recent studies of nitrogen containing heterocyclic compounds as novel antiviral agents: A review. Bioorg. Chem. 2021, 114, 105076.

[3] Jang, H.J.; Kim, S.M.; Rho, M.C.; Lee, S.W.; Song, Y.H. Synthesis of thienopyrimidine derivatives as inhibitors of STAT3 activation induced by IL-6. J. Microbiol. Biotechnol. 2019, 29, 856-862.

[4] Abdel-Megid, M.; Elmahdy, K.M.; Elkazak, A.M.; Seada, M.H.; Mohamed, O.F. Chemistry of thienopyrimidines and their biological applications. J. Pharm. Appl. Chem. 2016, 2, 103-127.

[5] Ali, E.M.H.; Abdel-Maksoud, M.S.; Oh, C.H. Thieno[2,3-d]pyrimidine as a promising scaffold in medicinal chemistry: Recent advances. Bioorg. Med. Chem. 2019, 27, 1159-1194.

[6] Rashad, A.E.; Shamroukh, A.H.; Abdel-Megeid, R.E.; Mostafa, A.; El-Shesheny, R.; Kandeil, A.; Ali, M.A.; Banert, K. Synthesis and screening of some novel fused thiophene and thienopyrimidine derivatives for antiavian influenza virus (H5N1) activity. Eur. J. Med. Chem. 2010, 45, 5251-5257.

[7] Ibrahim, Y.A.; Elwahy, A.H.M.; Kadry, A.M. Thienopyrimidines: Synthesis, reactions, and biological activity. Adv. Heterocycl. Chem. 1996, 65, 235-281.

[8] Zhuang, J.; Ma, S. Recent Development of pyrimidine-containing antimicrobial agents. ChemMedChem 2020, 15, 1875-1886.

[9] El-Dash, Y.; Elzayat, E.; Abdou, A.M.; Hassan, R.A. Novel thienopyrimidine-aminothiazole hybrids: Design, synthesis, antimicrobial screening, anticancer activity, effects on cell cycle profile, caspase-3 mediated apoptosis and VEGFR-2 inhibition. Bioorg. Chem. 2021, 114, 105137.

[10] El-Sayed, W.A.; Ali, O.M.; Zyada, R.A.F.; Mohamed, A.A.; Abdel-Rahman, A.A.H. Synthesis and antimicrobial activity of new substituted thienopyrimidines, their tetrazolyl and sugar derivatives. Acta Pol. Pharm. - Drug Res. 2012, 69, 439-447.

[11] Barrows, R.D.; Hammill, J.T.; Tran, M.C.; Falade, M.O.; Rice, A.L.; Davis, C.W.; Emge, T.J.; Rablen, P.R.; Kiplin Guy, R.; Knapp, S. Evaluation of 1,1-cyclopropylidene as a thioether isostere in the 4-thiothienopyrimidine (TTP) series of antimalarials. Bioor. Med. Chem. 2020, 28, 115758.

[12] Gonzàlez Cabrera, D.; Douelle, F.; Le Manach, C.; Han, Z.; Paquet, T.; Taylor, D.; Njoroge, M.; Lawrence, N.; Wiesner, L.; Waterson, D.; et al. Structure-activity relationship studies of orally active antimalarial 2,4diamino-thienopyrimidines. J. Med. Chem. 2015, 58, 7572-7579.

[13] Iman, M.; Davood, A.; Khamesipour, A. Design of antimalarial agents based on pyrimidine derivatives as methionine aminopeptidase $1 \mathrm{~b}$ inhibitor: Molecular docking, quantitative structure activity relationships, and molecular dynamics simulation studies. J. Chinese Chem. Soc. 2020, 67, 880-890.

[14] El-Sherbeny, M.A.; El-Ashmawy, M.B.; El-Subbagh, H.I.; El-Emam, A.A.; Badria, F.A. Synthesis, antimicrobial and antiviral evaluation of certain thienopyrimidine derivatives. Eur. J. Med. Chem. 1995, 30, 445-449.

[15] Ragab, F.A.; Heiba, H.I.; El-Gazzar, M.G.; Abou-Seri, S.M.; El-Sabbagh, W.A.; El-Hazek, R.M. Antiinflammatory, analgesic and COX-2 inhibitory activity of novel thiadiazoles in irradiated rats. J. Photochem. Photobiol. B Biol. 2017, 166, 285-300.

[16] Sondhi, S.M.; Singh, N.; Johar, M.; Kumar, A. Synthesis, anti-inflammatory and analgesic activities evaluation of some mono, bi and tricyclic pyrimidine derivatives. Bioorg. Med. Chem. 2005, 13, 6158-6166.

[17] Aghekyan, A.A.; Mkryan, G.G.; Panosyan, H.A.; Buniatyan, G.M.; Muradyan, R.E. Synthesis and antioxidant activity of ethyl 2-amino-6-cyano-6-phenyl-4,5,6,7-tetrahydro-1-benzothiophene-3-carboxylates and 3-amino-4-oxo-7-phenyl-3,4,5,6,7,8-hexahydrobenzo[4,5]thieno[2,3-d]pyrimidine-7-carbonitriles. Russ. J. Org. Chem. 2020, 56, 440-445. 
Synthesis and biological activity of thienopyrimidines

[18] Saundane, A.R.; Yarlakatti, M.; Walmik, P.; Katkarf, V. Synthesis, antioxidant and antimicrobial evaluation of thiazolidinone, azetidinone encompassing indolylthienopyrimidines. J. Chem. Sci. 2012, 124, 469-481.

[19] Abu-Hashem, A.A.; Al-Hussain, S.A.; Zaki, M.E.A. Design, synthesis and anticancer activity of new polycyclic: Imidazole, thiazine, oxathiine, pyrrolo-quinoxaline and thienotriazolopyrimidine derivatives. Molecules 2021, 26.

[20] Khattab, R.R.; Hassan, A.A.; A. Osman, D.A.; Abdel-Megeid, F.M.; Awad, H.M.; Nossier, E.S.; El-Sayed, W.A. Synthesis, anticancer activity and molecular docking of new triazolo[4,5- d ]pyrimidines based thienopyrimidine system and their derived $\mathrm{N}$-glycosides and thioglycosides. Nucleosides Nucleotid. Nucleic Acid. 2021, 40 (11), 1090-1113.

[21] Pokhodylo, N.T.; Shyyka, O.Y.; Slyvka, Y.I.; Goreshnik, E.A.; Obushak, M.D. Solvent-free synthesis of cytisine-thienopyrimidinone conjugates via transannulation of $1 \mathrm{H}$-tetrazoles: Crystal and molecular structure, docking studies and screening for anticancer activity. J. Mol. Struct. 2021, 1240, 130487.

[22] Al-snafi, A.E. International Journal for Pharmaceutical Research Scholars ( IJPRS ). 2014, 671-677.

[23] Rashid, H. ur; Martines, M.A.U.; Duarte, A.P.; Jorge, J.; Rasool, S.; Muhammad, R.; Ahmad, N.; Umar, M.N. Research developments in the syntheses, anti-inflammatory activities and structure-activity relationships of pyrimidines. RSC Adv. 2021, 11, 6060-6098.

[24] El-Shoukrofy, M.S.; Abd El Razik, H.A.; AboulWafa, O.M.; Bayad, A.E.; El-Ashmawy, I.M. Pyrazoles containing thiophene, thienopyrimidine and thienotriazolopyrimidine as COX-2 selective inhibitors: Design, synthesis, in vivo anti-inflammatory activity, docking and in silico chemo-informatic studies. Bioorg. Chem. 2019, 85, 541-557.

[25] Russell, R.K.; Press, J.B.; Rampulla, R.A.; Mcnally, J.J.; Falotico, R.; Reiser, J.A.; Bright, D.A.; Tobia, A. Thiophene thienopyrimidinedione antihypertensive. J. Med. Chem. 1988, 1786-1793.

[26] Pédeboscq, S.; Gravier, D.; Casadebaig, F.; Hou, G.; Gissot, A.; De Giorgi, F.; Ichas, F.; Cambar, J.; Pometan, J.P. Synthesis and study of antiproliferative activity of novel thienopyrimidines on glioblastoma cells. Eur. J. Med. Chem. 2010, 45, 2473-2479.

[27] Kaliraj, S.; Jeyalakshmi, R.; Kathiravan, M. K.; Madhavan, T.; Devi, A. Design, molecular docking and biological evaluation of fused thienopyrimidines and quinazoline. Asian J. Chem. 2021, 33 (3), 537-544.

[28] Oganisyan, A.S.; Noravyan, A.S.; Dzhagatspanyan, I.A.; Nazaryan, I.M.; Akopyan, A.G. Derivatives of condensed thienopyrimidines: Synthesis and anticonvulsant and tranquilizer activity of hydrochlorides of pyrano[4',3':4,5] thieno[3,2-e]imidazo[1,2-a]pyrimidines. Pharm. Chem. J. 2007, 41, 588-590.

[29] Kathiravan, M.K.; More, K.D.; Raskar, V.K.; Jain, K.S.; Maheshwar, M.; Gadhwe, S.; Jain, D.P.; Nagras, M.A.; Phoujdar, M.S. Synthesis and antihyperlipidemic activity of novel condensed 2fluoromethylpyrimidines. Med. Chem. Res. 2013, 22, 4286-4292.

[30] Tamboli, R.; Amrutkar, R.; Jain, K.; Kathiravan, M. Synthesis and in vivo antihyperlipidemic potential of novel substituted thieno[3,2-d]pyrimidines. Lett. Drug Des. Discov. 2013, 10, 906-915.

[31] Gryshchenko, A.A.; Bdzhola, V.G.; Balanda, A.O.; Briukhovetska, N. V.; Kotey, I.M.; Golub, A.G.; Ruban, T.P.; Lukash, L.L.; Yarmoluk, S.M. Design, synthesis and biological evaluation of N-phenylthieno[2,3d]pyrimidin-4-amines as inhibitors of FGFR1. Bioorg. Med. Chem. 2015, 23, 2287-2293.

[32] Li, J.; Gu, W.; Bi, X.; Li, H.; Liao, C.; Liu, C.; Huang, W.; Qian, H. Design, synthesis, and biological evaluation of thieno[2,3-d]pyrimidine derivatives as novel dual c-Met and VEGFR-2 kinase inhibitors. Bioorg. Med. Chem. 2017, 25, 6674-6679.

[33] Ts. Mavrova, A.; Dimov, S.; Yancheva, D.; Kolarević, A.; Ilić, B.S.; Kocić, G.; Šmelcerović, A. Synthesis and DNase I inhibitory properties of some 5,6,7,8-tetrahydrobenzo[4,5]thieno[2,3-d]pyrimidines. Bioorg. Chem. 2018, 80, 693-705.

[34] Milik, S.N.; Abdel-Aziz, A.K.; Lasheen, D.S.; Serya, R.A.T.; Minucci, S.; Abouzid, K.A.M. Surmounting the resistance against EGFR inhibitors through the development of thieno[2,3-d]pyrimidine-based dual EGFR/HER2 inhibitors. Eur. J. Med. Chem. 2018, 155, 316-336.

[35] Sirakanyan, S.N.; Geronikaki, A.; Spinelli, D.; Hakobyan, E.K.; Kartsev, V.G.; Petrou, A.; Hovakimyan, A.A. Synthesis and antimicrobial activity of new amino derivatives of pyrano[4', 3', :4',5']pyrido[3',2':4,5]thieno[3,2-d]pyrimidine. An. Acad. Bras. Cienc. 2018, 90, 1043-1057.

[36] Litvinov, V.P. Thienopyrimidines: Synthesis, properties, and biological activity. Russ. Chem. Bull. 2004, 53, 487-516.

[37] El-Batanony, N.H. Antimicrobial activities and mode of action of the selected novel thienopyrimidines derivatives 2-[2-(Diphenylmethylene) hydrazino]-5-isopropyl- -3-methylthieno [2, 3-d] pyrimidin-4-one. Period. Biol. 2017, 119, 27-36.

[38] Tolba, M.S.; Ahmed, M.; Kamal El-Dean, A.M.; Hassanien, R.; Farouk, M. Synthesis of new fused thienopyrimidines derivatives as anti-inflammatory agents. J. Heterocycl. Chem. 2018, 55, 408-418. 
Tolba et al., Org. Commun. (2021) 14:4 365-376

[39] Sayed, M.; Younis, O.; Hassanien, R.; Ahmed, M.; Mohammed, A.A.K.; Kamal, A.M.; Tsutsumi, O. Design and synthesis of novel indole derivatives with aggregation-induced emission and antimicrobial activity. $J$. Photochem. Photobiol. A Chem. 2019, 383, 111969.

[40] Sayed, M.; Kamal El-Dean, A.M.; Ahmed, M.; Hassanien, R. Design, synthesis, and characterization of novel pyrimidines bearing indole as antimicrobial agents. J. Chinese Chem. Soc. 2019, 66, 218-225.

[41] Tolba, M.S.; El-dean, A.M.K.; Ahmed, M.; Hassanien, R.; Sayed, M. Synthesis , reactions , and applications of pyrimidine derivatives. Curr. Chem. Lett. 2022, 11.121-138.

[42] Abdel-Raheem, S.A.A.; Kamal El-Dean, A.M.; Hassanien, R.; El-Sayed, M.E.A.; Sayed, M.; Abd-Ella, A.A. Synthesis and spectral characterization of selective pyridine compounds as bioactive agents. Curr. Chem. Lett. 2021, 10, 255-260.

[43] Tolba, M.S.; Sayed, M.; Abdel-Raheem, S.A.A.; Gaber, T.A.; Kamal El-Dean, A.M.; Ahmed, M. Synthesis and spectral characterization of some new thiazolopyrimidine derivatives. Curr. Chem. Lett. 2021, 10, 471478.

[44] Ahmed, M.; Younis, O.; Orabi, E.A.; Sayed, A.M.; Kamal El-Dean, A.M.; Hassanien, R.; Davis, R.L.; Tsutsumi, O.; Tolba, M.S. Synthesis of novel biocompatible thienopyrimidine chromophores with aggregation-induced emission sensitive to molecular aggregation. ACS Omega 2020, 5, 29988-30000.

[45] Ahmed, M.; Sayed, M.; Saber, A.F.; Hassanien, R.; Kamal El-Dean, A.M.; Tolba, M.S. Synthesis, Characterization, and Antimicrobial Activity of New Thienopyrimidine Derivatives. Polycycl. Aromat. Compd. 2020, 229-243.

[46] Younis, O.; Tolba, M.S.; Orabi, E.A.; Kamal, A.M.; Hassanien, R.; Tsutsumi, O.; Ahmed, M. BiologicallyActive Heterocyclic Molecules with Aggregation-Induced Blue-Shifted Emission and Efficient Luminescence both in Solution and Solid States. J. Photochem. Photobiol. A Chem. 2020, 400, 112642.

[47] Saber, A.F.; Sayed, M.; Tolba, M.S.; Kamal El-Dean, A.M.; Hassanien, R.; Ahmed, M. A facile method for preparation and evaluation of the antimicrobial efficiency of various heterocycles containing thieno[2,3d]pyrimidine. Synth. Commun. 2021, 51, 398-409.

[48] Abdel-Raheem, S.A.A.; Kamal El-Dean, A.M.; Hassanien, R.; El-Sayed, M.E.A.; Abd-Ella, A.A. Synthesis and characterization of some distyrylderivatives for agricultural uses. Eur. Chem. Bull. 2021, 10, 35-38.

[49] Abdel-raheem, S.A.A.; El-dean, A.M.K.; Hassanien, R.; Mohamed, E.A.; Abd-ella, A.A. Synthesis and biological activity of 2- (( 3-Cyano-4 , 6-distyrylpyridin-2-yl ) thio ) acetamide and its cyclized form. Alger. J. Biosciences 2020, 01, 046-050.

[50] Gad, M.A.; Aref, S.A.; Abdelhamid, A.A.; Elwassimy, M.M.; Abdel-Raheem, Sh.A.A. Biologically active organic compounds as insect growth regulators (IGRs): introduction, mode of action, and some synthetic methods. Curr. Chem. Lett. 2021, 10, 393-412.

[51] Kamal El-Dean, A.M.; Abd-Ella, A.A.; Hassanien, R.; El-Sayed, M.E.A.; Zaki, R.M.; Abdel-Raheem, Sh.A.A. Chemical design and toxicity evaluation of new pyrimidothienotetrahydroisoquinolines as potential insecticidal agents. Toxicol. Rep. 2019, 6, 100-104.

[52] Abdelhamid, A.A.; Elsaghier, A.M.M.; Aref, S.A.; Gad, M.A.; Ahmed, N.A.; Abdel-Raheem, Sh.A.A. Preparation and biological activity evaluation of some benzoylthiourea and benzoylurea compounds. Curr. Chem. Lett. 2021, 10, 371-376.

[53] Abdel-Raheem, Sh.A.A.; Kamal El-Dean, A.M.; Zaki, R.M.; Hassanien, R.; El-Sayed, M.E.A.; Sayed, M.; Abd-Ella, A.A. Synthesis and toxicological studies on distyryl-substituted heterocyclic insecticides. Eur. Chem. Bull. 2021, 10, 225-229.

[54] Abdel-Raheem, Sh.A.A.; Kamal El-Dean, A.M.; Abd ul-Malik, M.A.; Abd-Ella, A.A.; Al-Taifi, E.A.; Hassanien, R.; El-Sayed, M.E.A.; Mohamed, S.K.; Zawam, S.A.; Bakhite, E.A. A concise review on some synthetic routes and applications of pyridine scaffold compounds. Curr. Chem. Lett. 2021, 10, 337-362.

[55] Al-Taifi, E.A.; Abdel-Raheem, Sh.A.A.; Bakhite, E.A. Some reactions of 3-cyano-4-( $p$-methoxyphenyl)-5oxo-5,6,7,8-tetrahydroquinoline-2(1H)-thione; Synthesis of new tetrahydroquinolines and tetrahydrothieno[2,3-b]quinolines. Assiut Univ. J. Chem. (AUJC) 2016, 45, 24-32.

[56] Kamal El-Dean, A.M.; Abd-Ella, A.A.; Hassanien, R.; El-Sayed, M.E.A.; Abdel-Raheem, Sh.A.A. Design, synthesis, characterization, and insecticidal bioefficacy screening of some new pyridine derivatives. ACS Omega 2019, 4, 8406-8412.

[57] Bakhite, E.A.; Abd-Ella, A.A.; El-Sayed, M.E.A.; Abdel-Raheem, Sh.A.A. Pyridine derivatives as insecticides. Part 2: Synthesis of some piperidinium and morpholinium cyanopyridinethiolates and their insecticidal activity. J. Saud. Chem. Soc. 2017, 21, 95-104.

[58] Abdelhafeez, I.A.; El-Tohamy, S.A.; Abd ul-Malik, M.A.; Abdel-Raheem, Sh.A.A.; El-Dars, F.M.S. A review on green remediation techniques for hydrocarbons and heavy metals contaminated soil. Curr. Chem. Lett. 2022, 11, 43-62. 
Synthesis and biological activity of thienopyrimidines

[59] Tolba, M.S.; Abd ul-Malik, M.A.; Kamal El-Dean, A.M.; Geies, A.A.; Radwan, Sh.M.; Zaki, R.M.; Sayed, M.; Mohamed, S.K.; Abdel-Raheem, Sh.A.A. An overview on synthesis and reactions of coumarin based compounds. Curr. Chem. Lett. 2022, 11, 29-42.

[60] Abdel-Raheem, Sh.A.A.; Kamal El-Dean, A.M.; Abd ul-Malik, M.A.; Hassanien, R.; El-Sayed, M.E.A.; Abd-Ella, A.A.; Zawam, S.A.; Tolba, M.S. Synthesis of new distyrylpyridine analogues bearing amide substructure as effective insecticidal agents. Curr. Chem. Lett. 2022, 11, 23-28.

[61] Balouiri, M.; Sadiki, M.; Ibnsouda, S.K. Methods for in vitro evaluating antimicrobial activity: A review. J. Pharm. Anal. 2016, 6, 71-79.

$$
\underset{\substack{\text { publications } \\ \text { C) 2021 ACG Publications }}}{\mathrm{C}}
$$

